JMIAP
JURNAL ILMU ADMINISTRASI PUBLIK

Email : jianfis.unp@gmail.com

Vol.1 No.1 Tahun 2018

\title{
IMPLEMENTASI PENGELOLAAN KEUANGAN DENGAN TRANSAKSI NON TUNAI DI SEKRETARIAT DAERAH PROVINSI SUMATERA BARAT
}

\author{
Husna Rahma Dona \\ Jurusan Ilmu Administrasi Publik,Fakultas Ilmu Sosial, Universitas Negeri Padang \\ Email : husnarahmadona@gmail.com
}

Afriva Khaidir

Jurusan Ilmu Administrasi Publik,Fakultas Ilmu Sosial, Universitas Negeri Padang Email : afrivak@yahoo.com

\begin{abstract}
This study tried to explain the implementation of non-cash financial management at the Local Government Secretariat (Sekda) of West Sumatera, the obstacles that arise during implementation and the efforts to overcome these obstacles. This research was motivated by the presence of Surat Edaran Menteri Dalam Negeri Number 910/1866/SJ, dated April 17, 2017 concerning Non-Cash Implementation in Provincial Governments, in each Regional Government in all provinces in Indonesia is required to implement a non-cash transaction system in regional financial management. This research is descriptive with a qualitative approach. The indicator used in this study is accountability, transparency and value of money. Research informants were determined by purposive sampling. The results showed that implementation of financial management of non-cash at the Local Government Secretariat (Sekda) of West Sumatera, had begun in September 2017. The implementation of this online-based noncash transaction required a structured mechanism and flow for the implementation of the Standard Operating Procedure. But in its implementation, there are various obstacles that arise such as treasurers who have not all followed the flow in the SOP, applications that are still often errors, and the treasurer workload is increasing.
\end{abstract}

Keywords: non-cash transaction, financial management 


\section{JMIAP \\ jmiap.ppj.unp.ac.id}

Email : jianfis.unp@gmail.com

Vol.1 No.1 Tahun 2018

\section{Pendahuluan}

Negara Indonesia dengan kondisi geografi dan jumlah populasi yang cukup besar, memiliki potensi untuk melakukan perluasan akses layanan sistem pembayaran. Kelancaran sistem pembayaran melalui transaksi non-tunai merupakan faktor penentu keberhasilan terciptanya stabilitas sistem keuangan yang efektif. Mengacu kepada hal tersebut, Bank Indonesia sebagai regulator sekaligus bank sentral di Indonesia mengemukakan ide penggunaan instrumen pembayaran nontunai dengan membuat sebuah kampanye bertema "Gerakan Nasional Non Tunai (GNNT)".

Dalam mewujudkan "good governance clean government" pemerintah telah berupaya untuk memaksimalkan kebijakan transaksi non-tunai ini. Pemerintah Provinsi Sumatera Barat sendiri saat ini juga telah sepakat bekerja sama dengan Bank Nagari untuk mengembangkan transaksi keuangan nontunai di seluruh Organsasi Perangkat Daerah (OPD) di Provinsi Sumatera Barat untuk mewujudkan masyarakat tanpa transaksi tunai.

Sehubungan dengan tindaklanjut Surat Edaran Menteri Dalam Negeri No.910/1866/51-2017 tentang Implementasi Transaksi Non-Tunai pada pemerintahan Provinsi, Pemkab dan Kota sebagai tindak lanjut pelaksanaan Instruksi Presiden No.10/2016 Tetang Aksi Pencegahan dan Pemberantasan Korupsi Tahun 2016 dan Tahun 2017, Pemerintah Provinsi Sumatera Barat bekerjasama dengan Bank Nagari dalam menandatangani nota kesepakatan implementasi non-tunai di aula Bank Nagari tanggal 22 Sepetember 2017.
Bank Nagari menggagas Nagari Cash Management yang akan diterapkan pada awal Oktober 2017. Nagari Cash Management ini bertujuan untuk menerapkankan sistem transaksi keuangan daerah secara non-tunai. Dengan demikian semua transaksi keuangan yang bersumber dari kas daerah akan dilaksanakan dengan sistim non-tunai. Dalam penggunanaan Nagari Cash Management, petugas bendaharawan dan pengelola keuangan daerah tidak akan menggunakan brankas sebagai media penyimpanan uang lagi dan tidak akan ada peredaran uang cash di seluruh SKPD Provinsi Sumatera Barat.

Dengan diterapkannya sistem transaksi keuangan daerah secara non-tunai ini, Pemprov Sumbar akan menjadi provinsi kedua setelah DKI Jakarta yang mampu merealisasikan kebijakan nasional tersebut. Sosialisasi akan dilakukan secara bertahap dan setelah dilaunching bulan Oktober tahun 2017, ditargetkan pada bulan Desember keseluruhan sistem pendukung penerapan transaksi non tunai ini akan selesai dan siap untuk digunakan secara keseluruhan.

Dalam pelaksanaan transaksi keuangan daerah secara nontunai, Badan Keuangan Daerah selaku Bendahara Umum Daerah membuat sebuah Standar Operasional Prosedur agar makanisme atau alur sistem pembayaran dengan non-tunai dapat terarah dan berjalan lancar. Tetapi hingga sekarang masih ditemukan bahwa terdapat bendahara yang tidak mengikuti mekanisme yang sudah disediakan.

Berdasarkan wawancara peneliti dengan Bendahara di Biro Pemerintahan Sekda Provinsi Sumatera Barat, mengatakan bahwa terdapat beberapa kendala dalam penggunaan Nagari Cash Management; salah satunya yaitu jaringan internet seringkali tidak terhubung yang 
menyebabkan terhambatnya pekerjaan yang dilakukan oleh para bendahara. Kendala lainnya yang ditemui adalah aplikasi Nagari Cash Management yang akan error pada saat melakukan transaksi yang banyak secara sekaligus. Hal tersebut sangat berisiko bagi bendahara sehingga dibutuhkan ketelitian yang tinggi serta komunikasi yang lancar dengan rekan pelaku transaksi.

Lalu terdapat fasilitas bagi para bendahara dengan memberikan handphone untuk mempermudah melakukan transaksi dengan NCM tersebut. Handphone tersebut sudah di-setting agar hanya bisa mengakses aplikasi NCM. Tetapi kendala yang dirasakan oleh bendahara adalah untuk memperpanjang masa aktif kartu seluler agar bisa terus digunakan dengan menggunakan uang pribadi dari bendahara itu sendiri, sehingga fasilitas yang diberikan tersebut tidak bisa dimanfaatkan dengan baik oleh bendahara.

Berdasarkan permasalahan yang terdapat di latar belakang diatas, maka peneliti tertarik untuk melakukan penelitian mengenai Pelaksanaan Pengelolaan Keuangan dengan Transaksi Nontunai di Sekretariat Daerah Provinsi Sumatera Barat, maka rumusan masalah dalam penelitian adalah :

1. Bagaimana pelaksanaan pengelolaan keuangan transaksi non-tunai di Sekretariat Daerah Provinsi Sumatera Barat?

2. Apa sajakah kendala yang muncul dalam pelaksanaan transaksi non-tunai di Sekretariat Daerah Provinsi Sumatera Barat?

3. Apakah upaya dalam mengatasi kendala trasaksi non-tunai di Sekretariat Daerah Provinsi Sumatera Barat?

\section{Tinjauan Pustaka}

Implementasi, Kendala, dan Upaya
Implementasi menurut Purwanto dan Sulistyastuti (2012) adalah kegiatan untuk mendistribusikan keluaran kebijakan (to deliver output) yang dilakukan oleh para implementer kepada kelompok sasaran (target group) sebagai upaya untuk mewujudkan tujuan kebijakan. Grindle (1980) dalam Mulyadi (2016) menyatakan bahwa implementasi adalah proses umum tindakan administratif yang dapat diteliti pada tingkat program tertentu. Meter dan Horn dalam Muchlis (2004) berpendapat bahwa implementasi kebijakan merupakan semua tindakan oleh perorangan atau kelompok pemerintah maupun swasta yang diarahkan pada perwujudan tujuan yang telah ditetapkan terlebih dahulu dalam keputusan kebijakan.

Proses implementasi baru akan dimulai apabila tujuan dan sasaran telah ditetapkan, program kegiatan telah tersusun dan dana telah siap dan telah disalurkan untuk mencapai sasaran. Lalu menurut pemahaman peneliti, implementasi intinya merupakan tindakan yang dilakukan setelah suatu kebijakan ditetapkan implementasi merupakan cara agar sebuah kebijakan dapat mencapai suatu tujuan. Selanjutnya impelementasi kebijakan publik dapat dipahami bahwa tahap implementasi merupakan peristwa yang berhubungan dengan apa yang terjadi setelah suatu Undang-Undang atau peraturan ditetapkan dengan memberikan otoritas pada suatu kebijakan dengan membentuk output yang jelas dan dapat diukur.

Selanjutnya teori kendala atau Theory of Constraint merupakan suatu pendekatan ke arah peningkatan proses yang berfokus pada elemen yang dibatasi untuk meningkatkan output. Menurut Hansen dan Mowen dalam Setyaningrum \& Hamidy (2008) mengatakan theory of constraint adalah suatu teori yang memfokuskan 
perhatian manajer pada kendala atau pemborosan yang memperlambat proses produksi. Berdasarkan pengertian tersebut dapat dipahami bahwa TOC memfokuskan untuk mengidentifikasi kendala-kendala yang mempengaruhi proses produksi suatu perusahaan, kemudian mengoptimalkan penggunaan sumber daya yang memiliki kendala tersebut dalam meningkatkan keuntungan dan mencapai tujuan.

Terdapat dua kendala berdasarkan asalnya yaitu kendala internal dan kendala eksternal. Kendala internal adalah faktorfaktor yang membatasi berjalannya pelaksanaan kegiatan pengawasan yang berasal dari dalam sistemnya sendiri. Kendala internal harus ditekan secara optimal agar tujuan yang ingi dicapai dpat terlaksana tanpa harus meningkatkan biaya operasional. Kendala eksternal adalah faktor-faktor yang membatasi tujuan organisasi yang berasal dari luar sistemnya.

Kendala-kendala yang muncul tersebut akan diatasi dengan berbagai upaya. Menurut Kamus Besar Bahasa Indonesia tahun 2008 upaya merupakan usaha, ikhtiar untuk mencapai suatu maksud, memecahkan persoalan dan mencari jalan keluar.

Selanjutnya Poerwadaminta dalam Jupri (2014) mengatakan upaya adalah segala sesuatu yang bersifat mengusahakan terhadap sesuatu hal supaya dapat lebih berdaya guna dan berhasil guna sesuai dengan maksud, tujuan dan fungsi serta manfaat suatu hal tersebut dilaksanakan. Upaya sangat berkaitan erat dengan dengan penggunaan sarana dan prasarana dalam menunjang kegiatan tersebut, agar berhasil maka dilakukan suatu cara dan alat penunjang yang tersedia. Berdasarkan pengertian tersebut dapat penulis pahami bahwa upaya adalah suatu kegiatan atau usaha dengan menggunakan segala keuatan yang ada dalam mengatasi suatu masalah.

\section{Manajemen Pemerintah}

Bun Yamin Ramto dalam Nawawi (2013) menjelaskan manajemen pemerintahan adalah faktor utama dalam suatu administrasi publik untuk mencapai tujuan yang telah ditentukan dengan sarana dan prasarana yang ada, termasuk organisasi serta sumber dana dan sumber daya yang tersedia. Sedangkan Sondang P. Siagian dalam Nawawi (2013) mendefisinikan manajemen pemerintahan adalah manajemen yang ditetapkan dalam lingkungan aparatur pemerintahan atau aparatur negara, tidak hanya diartikan sebagai aparatur dari badan eksekutif, tetapi juga dari badan legislatif dan yudikatif, serta baik pada tingkat pusat maupun tingkat daerah.

Dengan demikian dapat peneliti pahami bahwa manajemen pemerintahan adalah berupa rumusan dari faktor upaya dalam suatu organisasi. Upaya tersebut diwujudkan dengan berbagai kegiatan pemerintah yang mencakup berbagai aspek kehidupan dan penghidupan warga negara dan masyarakatnya. Kemampuan menyelenggarakan pemerintahan sangat ditentukan oleh kecakapan manajerial dan eksponen pemerintahan dan berfungsinya sistem manajemen. Apabila pemerintah sudah berjalan dengan baik serta dalam tataran implementasinya telah mengakomodasi bebrapa komponen seperti demokratissi dan globalisasi, inovasi, dan masyarakat madani maka kepemerintahan yang ada telah berkualifikasi baik atau diistilahkan "good governance".

\section{Pengelolaan Keuangan Daerah}

Menurut Peraturan Pemerintah Nomor 58 Tahun 2005, Pengelolaan Keuangan Daerah adalah keseluruhan kegiatan yang 


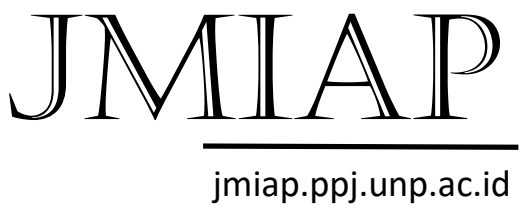

JURNAL ILMU ADMINISTRASI PUBLIK

Email : jianfis.unp@gmail.com

Vol.1 No.1 Tahun 2018

meliputi perencanaan, pelaksanaan, penatausahaan, pelaporan, pertanggungjawaban dan pengawasan keuangan daerah. Pengelolaan keuangan daerah yang dilakukan secara ekonomis, efisien, dan efektif dan sesuai prinsipprinsip good governance untuk dapat menciptakan pengelolaan yang akuntabel dan transparan. Selanjutnya menurut Soleh dan Rochmansjah (2010), prinsi-prinsip pengelolaan keuangan daerah adalah:

a. Akuntabilitas

Akuntabilitas merupakan

kewajiban organisasi dalam membuat perhitungan yang seksama dan mencatatnya dengan gambaran yang benar tentang transaksi finansial dan keadilan organisasi, lalu menyampaikan laporan tersebut pada laporan tahunan. terlihat bahwa akuntabilitas publik menghendaki birokrasi publik dapat menjelaskan secara transparan (transparency) dan terbuka (openness) kepada publik mengenai tindakan apa yang telah dilakukan.

b. Value for money

Menurut Mardiasmo (2009) value for money merupakan konsep pengelolaan organisasi sektor publik yang mendasarkan pada tiga elemen utama yaitu, efektivitas, efisiensi dan ekonomi. Value for money adalah istilah yang digunakan untuk menilai apakah organisasi telah memperoleh manfaat maksimal dari barang dan jasa yang diperoleh atau diberikan, dan dengan memanfaatkan sumber daya yang tersedia.

c. Transparansi

Tranparansi adalah keterbukaan pemerintah daerah dalam membuat kebijakan keuangan daerah sehingga dapat diketahui dan diawasi oleh DPRD

\begin{abstract}
dan masyarakat. Transparansi pengelolaan keuangan daerah pada akhirnya akan menciptakan horizontal accountability antara pemerintah daerah dengan masyarakat sehingga tercipta pemerintah daerah yang bersih, efektif, efisien, akuntabel dan responsif terhadap aspirasi dan kepentingan masyarakat.
\end{abstract}

\section{Transaksi Nontunai}

Sistem pembayaran dan pola bertransaksi ekonomi terus mengalami perubahan. Kemajuan teknologi dalam sistem pembayaran menggeser peranan uang tunai (currency) sebagai alat pembayaran non tunai yang lebih efisien dan ekonomis (Pramono, 2006). Selaku pemegang otoritas pelaksana sistem pembayaran nasional, Bank Indonesia menyadari sepenuhnya bahwa fungsi sistem pembayaran sangat kritikal dalam suatu perekonomian terutama untuk menjamin kestabilan sistem keuangan. Kelancaran sistem pembayaran melalui transaksi non-tunai merupakan faktor penentu keberhasilan terciptanya stabilitas sistem keuangan yang efektif. Mengacu kepada hal tersebut, Bank Indonesia sebagai regulator sekaligus bank sentral di Indonesia mengemukakan ide penggunaan instrumen pembayaran non-tunai dengan membuat sebuah kampanye bertema "Gerakan Nasional Non Tunai (GNNT)". Begitu pula dengan pemerintah saat ini yang sudah mencanangkan Gerakan Nasional Non Tunai yang telah dicanangkan oleh Bank Indonesia pada 14 Agustus 2014 dengan tujuan untuk meningkatkan kesadaran masyarakat terhadap penggunaan instrumen nontunai.

Terdapat beberapa manfaat dalam bertransaksi non-tunai yaitu:

1) Kepraktisan bertransaksi dan keamanan dalam membawa instrumen non tunai dibandingkan dengan uang tunai. 
2) Efisiensi biaya antara biaya produksi instrumen non-tunai dengan biaya pencetakan, peredaran serta pengelolaan uang tunai.

3) Pencatatan transaksi yang secara otomatis sehingga memudahkan dalam menghitung aktivitas ekonomi. Hal tersebut tentu dapat mencegah underground economy yang umumnya dilakukan dalam bentuk tunai.

4) Penggunaan alat pembayaran non tunai juga akan meningkatkan sirkulasi uang dalam perekonomian (velocity of money).

\section{Metode Penelitian}

Penelitian ini termasuk jenis penelitian kualitatif deskriptif, yaitu mengkaji objek yang mengungkapkan fenomena-fenomena yang ada secara konseptual melalui pengumpulan data yang diperoleh, dengan melihat unsur-unsur sebagai satuan objek kajian yang saling terkait selanjutnya mendiskripsikannya. Dengan menggunakan metode penelitian ini, peneliti akan membangun komunikasi dan berinteraksi dengan beberapa pihak yang dirasa berhubungan dengan permasalahan penelitian.

Teknik pengumpulan data dalam penelitian ini adalah wawancara, observasi dan studi dokumentasi. Dalam penentuan informan, peneliti menggunakan teknik purposive sampling. Informan dalam penelitian terdiri dari bendahara di birobiro pada Sekretariat Daerah Provinsi Sumatera Barat, serta Kasubid Pengeluaran di Bidang Perbendaharaan beserta staf di Badan Kauangan Daerah Sumatera Barat. Uji keabsahan data dilakukan menggunakan teknik triangulasi. Teknik analisis data dimulai dari reduksi data, penyajian data, dan penarikan kesimpulan.

\section{Hasil dan Pembahasan}

Hasil Temuan

\section{a. Pelaksanaan pengelolaan keuangan transaksi nontunai di Sekretariat Daerah Provinsi Sumatera Barat}

Transaksi non tunai telah menjadi pilihan bagi berbagai transaksi yang terjadi di wilayah Indonesia. Sistim transaksi non tunai ini menuju ke arah yang semakin efisien. Efisensi dari sistim transaksi nontunai ini dapat diukur dari tingkat keakuratan, ketepatan dan kecepatannya. Sehingga sistim non-tunai ini juga menjadi pilihan bagi Pemerintah Provinsi Sumatera Barat. Adapun pelaksanaan berbagai pembayaran secara transaksi non tunai diwujudkan sebagai salah satu upaya pembenahan tata kelola keuangan di Pemerintah Provinsi Sumatera Barat.

Pada saat ini, Pemerintah Provinsi Sumatera Barat baru bisa menerapkan transaksi non-tunai terbatas pada seluruh SKPD di Provinsi saja, karena dalam masa pengembangan dan dilakukan secara bertahap. Pada tahun 2017 berdasarkan Surat Edaran Menteri dalam negeri Nomor 910/186/SJ menerangkan bahwa pelaksanaan transaksi non tunai yang di ujicobakan di Sekretariat Daerah Provinsi Sumatera Barat dilakukan secara terbatas, maksudnya adalah pembayaran yang nominalnya dibawah Rp. 1.000.000 atau satu juta rupiah, masih bisa dilakukan dengan cash. Tetapi jika nominalnya sudah diatas satu juta rupiah, maka akan diwajibkan untuk melakukan pembayaran secara non tunai.

Pada tanggal 1 Januari tahun 2018, pelaksanaan transaksi non-tunai tersebut dilakukan secara menyeluruh di semua SKPD Provinsi di Sumatera Barat sesuai dengan Instruksi Gubernur Nomor 03 Tahun 2017 yang telah disebutkan sebelumnya. Berarti pada tanggal tersebut, semua brankas bendahara telah kosong, peredaran uang cash dilingkungan SKPD 


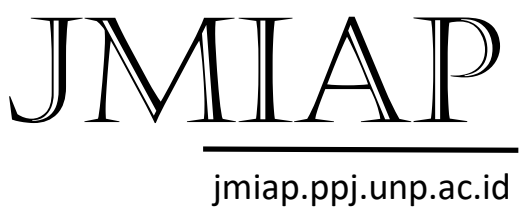

JURNAL ILMU ADMINISTRASI PUBLIK

Email : jianfis.unp@gmail.com

Vol.1 No.1 Tahun 2018

Provinsi Sumatera Barat sudah tidak ada. Keseluruhan jenis belanja daerah dilakukan secara non-tunai.

Sesuai dengan Instruksi Gubernur No. 3 Tahun 2017 tentang Pelaksanaan Transaksi Non-Tunai, terdapat pada poin ke-2 menjelaskan bahwa transaksi pembayaran melalui mekanisme non-tunai dilakukan untuk pembayaran :

a. Belanja perjalanan dinas dalam daerah

b. Belanja perjalanan dinas luar daerah

c. Belanja makanan dan minuman

d. Belanja horarium PNS dan Non-PNS

e. Belanja Alat Tulis Kantor, Peralatan, Perlengkapan Pakai Habis, Seminar Kit, Belanja Cetak dan Penggandaan.

Inovasi cashless yang dilakukan oleh Pemerintah dengan mengikuti issue nasional yaitu Gerakan Nasional NonTunai ini adalah untuk meningkatkan transparansi dan pertanggungjawaban pemerintah daerah terhadap apa yang telah dikerjakannya. Dan salah satu tujuan utama dalam pelaksanaan non-tunai ini adalah untuk menghilangkan budaya korupsi atau mark up anggaran yang biasanya terjadi di kalangan pemerintah daerah.

Perbedaan yang paling mencolok adalah metode pembayarannya dari cash menjadi cashless tetapi prinsip pengelolaan keuangan daerah yang menjadi pedoman bendahara masih sama. Pertanggungjawaban keuangan, metode pencatatan, dan pengakuan dalam akuntansi masih sama. Untuk pedoman pengelolaan keuangan daerah secara umum aturan yang masih berlaku sama yaitu Peraturan Menteri Dalam Negeri Nomor 13 Tahun 2006, dengan perubahan ada dua yaitu Peraturan Menteri Dalam Negeri Nomor 59 Tahun 2007, Peraturan Menteri Dalam Negeri Nomor 21 Tahun 2011.
Walaupun hanya metode pembayaran yang berubah, tetapi dengan menggunakan non-tunai berbasis perbankan ini, menghasilkan output yang berbeda dari sebelumnya. Cara bayar yang beda pasti ada output yang beda juga. Selanjutnya Pemerintah Provinsi Sumatera Barat, telah melakukan kerjasama dengan Bank Nagari sebagai penyelenggara dan fasilitator dalam pelaksanaan transaksi nontunai. Dengan menggunakan aplikasi Nagari Cash Management, yaitu salah satu jenis jasa layanan keuangan yang ditujuan untuk nasabah perorangan dan nonperorangan (perusahaan/lembaga) dimana nasabah yang bersangkutan dapat memperoleh informasi keuangan dan melakukan transaksi keuangan melalui fasilitas online.

Implementasi non tunai Pemprov Sumbar dimulai dari rapat pembangunan sistem dengan bank Nagari, selanjutnya sosialisasi awal kepada SKPD, penyelesaian regulasi pendukung, penetapan belanja yang akan dilakukan non tunai, uji coba Cash Management Systems dan yang terakhir bimtek bagi bendahara. Suksesnya transaksi non tunai apabila komitmen kuat, adanya perubaham mindset, regulasi, penguatan sumber daya manusia, dan yang terakhir kesiapan teknologi informasi. Manfaat dari transaksi nontunai tersebut, transaksi mudah diawasi, lebih efisien, relatif tidak berbiaya mahal, berkontribusi terhadap penerimaan daerah, memberi kemudahan transaksi pembayaran, dan dapat mencegah peredaran uang palsu.

Pelaksanan transaksi non tunai di daerah paling lambat pada tanggal 01 Januari 2018. Sebanyak 117 (seratus tujuh belas) Bendahara di Lingkungan Pemerintah Provinsi Sumatera Barat diharapkan dapat mengimplementasikan 
Nagari Cash Management terhitung 1 Oktober 2017 dalam melakukan pembayaran kepada pihak ketiga atau belanja rutin lainnya. Nagari Cash Management ini memang baru dan masih tahap pengembangan dan akan terus disempurnakan, diharapkan bendahara dapat secara optimal memanfaatkan fitur fitur yang sudah disiapkan, sehingga bendahara dapat melakukan tugasnya secara efektif dan efisien.

Pelaksanaan non-tunai di

Pemerintah Provinsi Sumatera Barat mencakup segala jenis APBD yang terbagi dalam Pendapatan dan Belanja Daerah. Dari sisi Pendapatan mencakup segi penerimaan pajak daerah, dan Penerimaan Asli Daerah lainnya dimana dari sisi penerimaan tersebut pengembangan sistem aplikasi untuk non tunai sudah dilakukan secara online sistem. Dimana penerimaan pendapatan dilakukan secara sistem online perbankan melalui auto debit yang masuk langsung ke rekening pendapatan pemerintah secara akuntabel dan transparan sudah dikelola dengan baik tanpa adanya lagi pungutan dimanapun.

Dari sisi Belanja Daerah penerapan transaksi non tunai mencakup berbagai aspek belanja seperti belanja subsidi/layanan publik, belanja pembangunan dan belanja rutin. Dalam kegiatan Belanja Daerah proses pelaksanaan transaksi non tunai dilakukan secara bertahap dimana awal pelaksanaannya Pemerintah Provinsi Sumatera Barat dibawah Badan Keuangan Derah Provinsi Sumatera Barat melakukan berbagai pendekatan terhadap stakeholder atau pihak ketiga dengan melakukan berbagai macam bentuk kerjasama.

Aplikasi Nagari Cash Management digunakan sebagai aplikasi yang membantu dalam pengelolaan Anggaran Pendapatan dan belanja Daerah di Sumatera Barat. Aplikasi yang digunakan yaitu Nagari Cash Management ini digunakan sebagai instrumen pembayaran pada seluruh belanja daerah. Pembayaran yang dilakukan oleh bendahara secara langsung dilakukan dengan sistim online yakni nontunai, dengan ketentuan yang masih sama pada tugas dan fungsi bendahara pengeluaran sesuai dengan Peraturan Menteri Dalam Negeri Nomor 55 Tahun 2008 tentang Pengelolaan Keuangan Daerah.

Belanja daerah yang dimaksudkan disini adalah berupa belanja rutin, belanja pegawai, belanja barang dan jasa misalnya pemenuhan Alat Tulis Kantor, belanja perjalanan dinas, belanja makanan dan minuman kegiatan. Selanjutnya belanja daerah tersebut hanya bisa digunakan pada Uang Persediaan. Uang Persediaan (UP) adalah uang muka kerja dengan jumlah tertentu yang bersifat daur ulang (revolving), diberikan kepada bendahara pengeluaran hanya untuk membiayai kegiatan operasional kantor sehari-hari yang tidak dapat dilakukan dengan pembayaran langsung. Dalam pembayaran makan dan minum kegiatan seperti kegiatan rapat harus melalui mekanisme yang terstruktur. Pembayaran belanja makan dan minum kegiatan, para staf atau PPTK (Pejabat Pelaksana Teknis Kegiatan) haruslah melengkapi persayaratan dokumen pertanggungjawaban kepada bendahara, jika dokumen tersebut sudah lengkap maka bendahara akan melakukan pembayaran kepada pihak ketiga atau pihak penyedia makan dan minum.

Perbedaan pembayaran transaksi nontunai dengan metode yang sebelumnya yaitu tunai adalah pembayaran dengan transaksi non tunai ini akan memutus rantai transaksi pembayaran antara PPTK atau 
staf dengan pihak ketiga penyedia makan dan minum. Karena sebelumnya pada saat itulah sering terjadi mark up anggaran yang tidak diketahui oleh bendahara. Oleh sebab itu dengan transaksi nontunai yang telah dilaksanakan pada saat ini diharapkan dapat menghindari kecurangan-kecurangan yang terjadi seperti sebelumnya. Karena bendahara yang langsung mentransfer pembayaran kepada penyedia makan dan minum kegiatan, bukan lagi melalui staf atau PPTK.

Standar Operasional Prosedur Belanja Perjalanan Dinas Dalam dan Luar Daerah, dalam pembayaran belanja tersebut, para PPTK (Pejabat Pelaksana Teknis Kegiatan) terlebih dahulu haruslah melengkapi persyaratan dokumen pertanggungjawaban dengan selengkaplengkapnya. Jika dokumen tersebut tidak lengkap, maka biaya perjalanan dinas dalam atau luar daerah tidak akan diproses oleh bendahara dan akan dikembalikan lagi kepada staf untuk dilengkapi sesuai persyaratan yang telah ditentukan.

Hal tersebut mengakibatkan dampak yang positif bagi produktivitas pegawai, karena pada sistim sebelumnya yaitu pembayaran cash bendahara akan melakukan transaksi pembayaran sebelum dokumen pertanggung jawaban dilengkapi, sehingga banyak staf atau PPTK yang tidak menyelesaikan dokumen pertanggungjawaban dengan tepat waktu.

Penggunaan $e$-card atau $e$-money juga merupakan bentuk kerjasama Pemerintah Provinsi Sumatera Barat dengan Bank Nagari maupun bank swasta lainnya dalam rangka transparasi atas pendapatan yang diperoleh Pemprov dan meminimalisir bentuk peredaran uang di masyarakat khususnya masyarakat di wilayah Provinsi Sumatera Barat. b. Kendala yang muncul dalam pelaksanaan pengelolaan keuangan transaksi nontunai di Sekretariat Daerah Provinsi Sumatera Barat Berdasarkan pada hasil penelitian yang telah penulis lakukan, terdapat beberapa kendala dalam pelaksanaan transaksi nontunai di Sekda Provinsi Sumatera Barat. diantaranya yaitu dalam pelaksanaan sistim non-tunai,disini berpengaruh kepada rekanan atau relasi dalam penyelenggaraan kegiatan yang diadakan di Sekretariat Daerah Provinsi Sumatera Barat. Para pegawai di Kantor Gubernur harus mencari rekanan atau relasi dari pihak ketiga yang mau melakukan transaksi pembayaran secara non-tunai dengan membuka rekening Bank Nagari. Hal tersebut tidaklah mudah karena terkadang beberapa restoran atau penyedia alat kantor tidak mau membuka rekening yang sesuai. Selanjutnya fasilitas yang diberikan oleh pihak ketiga yaitu Bank Nagari belum bisa dimanfaatkan dengan baik oleh para pengelola keuangan seperti PPK dan Bendahara. Fasilitas yang diberikan kepada petugas pengelolaan keuangan tersebut seharusnya disesuaikan dengan kapasitas pegawai dan efisien dalam penggunaannya. Karena pulsa yang tidak bisa digunakan akan mubazir atau terbuang percuma, terlebih pulsa tersebut berasal dari pengeluaran pribadi dari bendahara.

Dengan perkembangan teknologi, dapat mempermudah pekerjaan semua kalangan dan aspek, tetapi pada kenyataannya bendahara mengalami beban kerja yang bertambah banyak akibat adanya pelaksanaan transaksi non-tunai ini. Seharusnya penyelenggara sistim transaksi non-tunai di Provinsi Sumatera Barat yaitu Badan Keuangan Daerah Provinsi Sumatera Barat, mempertimbangkan dampak yang ditimbulkan dari suatu pelaksanaan kebijakan. Terkait efisiensi 
seharusnya pengelolaan keuangan dengan sistem online sudah dapat meminimalkan penggunaan kertas serta dapat memanfaatkan waktu untuk bekerja dalam meningkatkan produktivitas, tetapi kenyataan di lapangan masih belum efisien. Selanjutnya terdapat banyak kendala yang dirasakan oleh para bendahara yang termasuk pada kendala sistim dari aplikasi Nagari Cash Management. Kendala yang sering muncul adalah terjadi double transfer, atau transaksi yang dilakukan sudah berhasil tetapi laporannya tidak ada. Ini bukanlah kesalahan dari human-made, tetapi karena masalah aplikasi yang masih error. Jadi kami akan menghubungi pihak Bank Nagari untuk melaporkan kesalahan ini, tetapi terkadang laporan tersebut lama untuk ditindaklanjuti dan jikalau ada respon dari pihak bank para bendahara akan menunggu lama dalam proses perbaikan tersebut. Itu berpengaruh kepada pekerjaan, karena akan terhambat untuk proses lainnya. Kendala yang dialami oleh bendahara sebagian besar berupa kendala yang berasal dari sistim aplikasi. Seperti terjadinya kesalahan transfer saat melakukan transaksi, ataupun kesalahan double transfer yang masih sering terjadi. Dalam penanganan kendala tersebut, bendahara harus menghubungi pihak ketiga pemfasilitasi penyelenggaraan transaksi non-tunai yaitu Bank Nagari, tetapi untuk menunggu respon atau tanggapan dari Bank Nagari tersebut masih membutuhkan waktu yang lama.

c. Upaya dalam mengatasi kendala yang muncul dalam pelaksanaan transaksi keuangan secara non-tunai di Sekretariat Derah Provinsi Sumatera Barat

Berdasarkan hasil temuan penelitian yang telah penulis lakukan sebelumnya, terdapat beberapa upaya yang dilakukan untuk mengatasi berbagai kendala. Salah satunya yaitu upaya yang dilakukan oleh Badan Keuangan Daerah Provinsi Sumatera Barat adalah mengadakan kegiatan pelatihan atau pembinaan yang bernama 'Coaching Clinic' yang bertujuan untuk membina dan meningkatkan kemampuan pegawai dalam menggunakan aplikasi Nagari Cash Management sebagai instrumen pengelolaan keuangan daerah berbasis sistem online. Lalu upaya lain yang dilakukan adalah menjadi penghubung komunikasi yang baik antara para pengelola keuangan dan bendahara dengan pihak ketiga yaitu Bank Nagari agar komunikasi terkait keluhan akan kendala yang muncul dapat ditanggapi dengan cepat.

Kendala-kendala seperti kesalahan sistem, aplikasi error, jaringan atau koneksi internet yang buruk, merupakan kendala yang sangat mengahmbat pekerjaan para bendahara. Sehingga upaya dalam mengatasi kendala tersebut dilakukan bukan hanya dari pihak penyelenggara saja, melainkan juga berasal dari pengguna dari sistim non-tunai ini yaitu bendahara dan petugas pengelola keuangan. Hal tersebut dilakukan karena infrastruktur pendukung dalam pelaksanaan sistim transaksi nontunai ini belum memadai, sehingga atas berdasar inisiatif dari SKPD masingmasing maka dilakukan suatu cara agar pekerjaan tetap berjalan tanpa gangguan atau kesalahan teknis. Tetapi terkait dengan kendala aplikasi error masih belum ada upaya yan dilakukan oleh pihak penyelenggara selain dari upaya perbaikan yang masih lama ditanggapi.

\section{Pembahasan}


a. Pelaksanaan pengelolaan keuangan transaksi nontunai di Sekretariat Daerah Provinsi Sumatera Barat

Terdapat tiga indikator dalam penelitian ini dalam melihat pelaksanaan transaksi nontunai di Sekretariat Daerah Provinsi Sumatera Barat yaitu :

\section{Akuntabilitas}

Akuntabilitas merupakan kewajiban organisasi dalam membuat perhitungan yang seksama dan mencatatnya dengan gambaran yang benar tentang transaksi finansial dan keadilan organisasi, lalu menyampaikan laporan tersebut pada laporan tahunan. Terlihat bahwa akuntabilitas publik menghendaki birokrasi publik dapat menjelaskan secara transparan (transparency) dan terbuka (openness) kepada publik mengenai tindakan apa yang telah dilakukan. Yang menurut Islamy dalam Widodo (2001) tujuannya adalah untuk menjelaskan bagaimanakah pertanggungjawaban hendak dilaksanakan, metode apa yang dipakai untuk melaksanakan tugas, bagaimana realitas pelaksanaannya dan apa dampaknya.

Dapat penulis analisa bahwa dari segi akuntabilitas pelaksanaan transaksi keuangan secara non-tunai di Sekretariat Daerah sudah baik. Bisa dikatakan baik karena dengan adanya transaksi nontunai dengan berbasis sistim online ini, maka akan mendukung dalam pencapaian pemerintahan yang akuntabel. Dalam menyiapkan pengelolaan keuangan yang akuntabel dan, pelaksanaan transaksi non tunai merupakan salah satu upaya demi mensukseskan implementasi non-tunai secara keseluruhan menuju terwujudnya akuntabilitas pengelolaan keuangan daerah dan demi terwujudnya pemerintahan yang baik (good governance).

Dengan menggunakan aplikasi Nagari Cash Management, penerapan sistim transaksi non-tunai ini memudahkan bendahara dalam proses penghitungan pengeluaran, karena sistimnya dana yang akan bisa dikeluarkan dengan sistim transfer perbankan, sebelumnya urusan administrasi seperti SPJ atau laporan terlebih dahulu harus di-entry-kan kedalam sistem aplikasi. Jika SPJ dan laporan tersebut sudah lengkap maka proses transaksi baru akan dilakukan.

Akuntabilitas yang ingin dicapai dari pelaksanan non tunai ini adalah penggunaan APBD yang tepat sasaran dan akuntabel, karena seluruh aliran dana dapat ditelusuri danhasil akhir saldo perhitungan dalam pencatatan sama dengan saldo yang ada dalam rekening dan secara berkala akan tersaji didalam sistem dengan bukti pertanggung jawaban yang jelas.

Pengelolaan keuangan dengan sistim transaksi non-tunai ini juga berdampak pada produktivitas pegawai. Pegawai akan lebih dSisiplin dan lebih produktif untuk menyelesaikan dengan baik dan cepat segala SPJ atau laporan yang menjadi kewajibannya. Maka dengan sistem tersebut, akan terlihat bahwa dari segi akuntabililitas pelaksanaan Nagari Cash Management dalam pengelolaan keuangan daerah berjalan baik.

\section{Transparansi}

Transparansi merupakan keterbukaan pemerintah daerah dalam membuat kebijakan keuangan daerah sehingga dapat diketahui dan diawasi oleh DPRD dan masyarakat. Transparansi pengelolaan keuangan daerah pada akhirnya akan menciptakan horizontal accountability antara pemerintah daerah dengan masyarakat sehingga tercipta pemerintah daerah yang bersih, efektif, efisien, akuntabel dan responsif terhadap aspirasi dan kepentingan masyarakat. 


\begin{abstract}
Prinsip keterbukaan yang memungkinkan masyarakat untuk mengetahui dan mendapatkan akses informasi seluas-luasnya tentang keuangan daerah.
\end{abstract}

Pengelolaan keuangan atas pelaksanaan non tunai di Pemerintah Provinsi Sumatera Barat, saat ini secara tidak langsung sudah diketahui oleh publik, dikarenakan setiap transaski keluar masuk uang yang melalui APBD sudah berupa non cash, dan sudah menggunakan online sistem berbasis perbankan.

Berdasarkan wawancara yang sudah peneliti lakukan dengan informan, maka pelaksanaan transaksi keuangan secara non-tunai sudah mendukung asas transparansi. Karena dengan sistim nontunai maka segala pembelanjaan daerah dan penerimaan daerah akan dikelola dengan secara online. Dan dengan prinsip ini, pengelolaan keuangan yang dilakukan oleh para pengelola keuangan dan bendahara dapat dilaksanakan dengan lebih baik dan terbuka. Karena sudah tidak ada lagi "underground money" yang muncul dengan sistim non-tunai ini.

Bentuk transparansi yang didapat bagi masyarakat belum sepenuhnya diperoleh, tetapi bentuk transparansi yang telah diupayakan oleh Pemerintah Provinsi Sumatera Barat saat ini diantaranya adanya layanan akses data keuangan yang diberikan secara terbuka melalui websitewebsite resmi dari Pemerintah Provinsi Sumatera Barat seperti yang bisa diakses www.sumbarprov.go.id.

Oleh karena itu, pelaksanaan transaksi keuangan daerah secara non-tunai di Sekretariat Daerah Provinsi Sumatera Barat sudah baik dari segi transparansi. Walaupun belum memungkinkan masyarakat untuk mengakses informasi seluas-luasnya tentang pengelolaan keuangan yang dilakukan, tetapi dengan sudah adanya perubahan sistim dari tunai ke non-tunai ini, berarti telah ada upaya dari Pemerintah Provinsi Sumatera Barat dalam memperbaiki sistim yang ada ke arah yang lebih baik untuk mewujudkan tata kelola pemerintah yang baik.

\section{Value for money}

Value for money merupakan jembatan untuk menghantarkan pemerintah daerah mencapai good governance. Value for money tersebut harus dioperasionalkan dalam pengelolaan keuangan daerah dan anggaran daerah. Untuk mendukung dilakukannya pengelolaan keuangan dana publik (public money) maka diperlukan sistem pengelolaan keuangan daerah dan anggaran yang baik. hal tersebut dapat tercapai apabila pemerintah daerah memiliki sistem akuntansi yang baik.

Berdasarkan hasil temuan dapat peneliti analisa bahwa dari segi value for money yaitu bagaimana penerapan sistem transaksi non-tunai dalam pengelolaan keuangan daerah bisa dikatakan belum berjalan baik. Karena terdapat berbagai kendala di dalam penggunaan aplikasi Nagari Cash Management tersebut, seperti belum lancarnya aplikasi Nagari Cash Management tersebut masih error, masih sering terjadi kesalahan akibat aplikasi yang belum berjalan sempurna.

Selanjutnya jika dilihat dari segi efektivitas, pelaksanaan transaksi nontunai dalam pengelolaan keuangan daerah sudah efektif, karena bisa dikatakan tujuan-tujuan dari pelaksaan transaksi nontunai ini sudah tercapai walaupun masih terdapat beberapa kendala. Berdasarkan hasil wawancara, pekerjaan bendahara dan petugas pengelola keuangan (PPK) dapat dikerjakan dengan lebih mudah dan lebih tertib. Walaupun dari segi efisiensi masih belum sepenuhnya efisien karena terkendala pengaharusan 
mem-print bukti transfer di setiap pembayan yang dilakukan oleh bendahara dengan relasi kegiatan.

\section{b. Kendala yang muncul dalam pelaksanaan} pengelolaan keuangan transaksi nontunai di Sekretariat Daerah Provinsi Sumatera Barat Menurut Hansen dan Mowen (dalam Setyaningrum \& Hamidy, 2008) terdapat dua kendala berdasarkan asalnya yaitu:

1) Kendala internal

Kendala internal adalah faktor-faktor yang membatasi berjalannya pelaksanaan kegiatan pengawasan yang berasal dari dalam sistemnya sendiri. Kendala internal harus ditekan secara optimal agar tujuan yang ingi dicapai dpat terlaksana tanpa harus meningkatkan biaya operasional.Berdasarkan hasil wawancara yang telah peneliti lakukan dengan beberapa informan, maka dapat dilihat yang menjadi kendala internal adalah terdapat pada sistem aplikasi yang belum sempurna.

Maksudnya disini adalah masih sering terjadinya kesalahan yang diakibatkan oleh sistem aplikasi yang error. Seperti misalnya terjadi double transfer yang bukan karena kesalahan dari bendahara tetapi dari sistem aplikasi, kendala double transfer masih sering dikeluhkan oleh para bendahara karena hal tersebut akan mengakibatkan dampak yang panjang. Hal tersebut sangat tidak efektif bagi bendahara yang pekerjaannya akan terhambat.

Lalu karena aplikasi Nagari Cash Management berguna untuk mempermudah semua pembayaran dan segala transaksi, maka memberikan dampak pada beban kerja bendahara yang bertambah banyak. Hal tersebut sudah dikeluhkan oleh bendahara tetapi belum ada upaya penyelesaian dari pihak Badan Keuangan Daerah sebagai penyelenggara.
Kendala yang ditemukan selanjutnya adalah fasilitas berupa peminjaman handphone untuk melakukan pembayaran token listrik yang diberikan oleh pihak ketiga yaitu Bank Nagari belum bisa dimanfaatkan dengan baik oleh para pengelola keuangan seperti PPK dan Bendahara. Seharusnya fasilitas yang diberikan kepada petugas pengelolaan keuangan tersebut seharusnya disesuaikan dengan kapasitas pegawai dan efisien dalam penggunaannya. Karena pulsa yang tidak bisa digunakan akan mubazir atau terbuang percuma, terlebih pulsa tersebut berasal dari pengeluaran pribadi dari bendahara.

2) Kendala eksternal

Kendala eksternal adalah faktor-faktor yang membatasi tujuan organisasi yang berasal dari luar sistemnya. Berdasarkan hasil wawancara yang telah dilakukan, peneliti melihat terdapat beberapa kendala eksternal dalam pelaksanaan transaksi keuangan daerah secara nontunai di Sekretariat Daerah Provinsi Sumatera Barat diantaranya yaitu komunikasi antara bendahara dengan pihak Bank Nagari masih belum lancar. Hal tersebut terjadi pada saat bendahara melaporkan kendalakendala terkait aplikasi yang error, tetapi pihak Bank Nagari sering terlambat dalam memproses laporan tersebut.

Kendala lainnya adalah karena fasilitator aplikasi NCM adalah Bank Nagari maka direkomendasikan seluruh proses transaksi dilakukan antar sesama pengguna/nasabah bank Nagari. Tetapi dikenyataannnya rekanan yang berasal dari luar Sumatera Barat banyak yang keberatan akan hal tersebut.

\section{c. Upaya dalam mengatasi kendala yang} muncul dalam pelaksanaan transaksi 


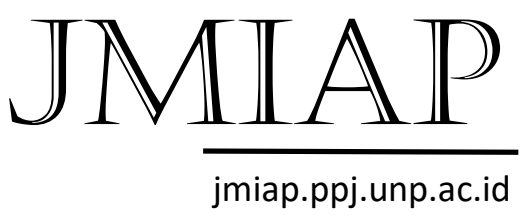

JURNAL ILMU ADMINISTRASI PUBLIK

Email : jianfis.unp@gmail.com

Vol.1 No.1 Tahun 2018

\section{keuangan secara non-tunai di Sekretariat Derah Provinsi Sumatera Barat}

Upaya adalah segala sesuatu yang bersifat mengusahakan terhadap sesuatu hal supaya dapat lebih berdaya guna dan berhasil guna sesuai dengan maksud, tujuan dan fungsi serta manfaat suatu hal tersebut dilaksanakan. Upaya sangat berkaitan erat dengan dengan penggunaan sarana dan prasarana dalam menunjang kegiatan tersebut, agar berhasil maka dilakukan suatu cara dan alat penunjang yang tersedia. Berdasarkan pengertian tersebut dapat penulis pahami bahwa upaya adalah suatu kegiatan atau usaha dengan menggunakan segala keuatan yang ada dalam mengatasi suatu masalah.

Demikian halnya dengan upaya yang dilakukan dalam mengatasi kendala yang timbul dalam pelaksanaan transaksi non tunai di Sekda Provinsi Sumatera Barat. Upaya yang dilakukan melibatkan instansi terkait yaitu Badan Keuangan Daerah bidang Perbendaharan selaku Bendahara Umum Daerah yang akan memberikan pembinaan kepada bendahara di lingkungan Pemprov Sumatera Barat. upaya yang dilakukan juga menggunakan sarana-prasarana yang ada ataupun tambahan untuk meningkatkan kinerja bendahara dalam mengantisipasi kendala sistem dan aplikasi.

\section{Penutup}

Berdasarkan beberapa hasil penelitian dan pembahasan sebelumnya, maka peneliti dapat menarik kesimpulan bahwa: Pelaksanaan transaksi keuangan secara nontunai di Sekretariat Daerah Provinsi Sumatera Barat telah dimulai pada bulan September tahun 2017. Dalam pelaksanaan tersebut telah dibentuk Standar Operasional
Prosedur untuk para bendahara di seluruh SKPD (Satuan Kerja Perangkat Daerah) di Provinsi Sumatera Barat. Pelaksanaan transaksi nontunai berdampak pada peningkatan akuntabilitas, transparansi dan value of money adalah seluruh aliran dana dapat ditelusuri, pencatatan transaksi sudah secara langsung dan adanya bukti pertanggungjawaban yang lengkap dan hal tersebut mewujudkan tertib administrasi pengelolaan keuangan daerah.

Kendala yang muncul dalam Pelaksanaan Transaksi Keuangan Daerah secara non-tunai di Sekretariat Daerah Provinsi Sumatera Barat adalah didominasi oleh kendala internal yaitu aplikasi yang sering error, bendahara yang masih melakukan transaksi nontunai tidak sesuai dengan SOP (Standar Operasional Prosedur) yang berlaku, fasilitas handphone yang diberikan tidak dapat digunakan dengan efektif dan efisien, serta beban kerja bendahara yang bertambah banyak. Selanjutnya kendala eksternal yang muncul adalah bendahara yang melaporkan kendala dalam pengoperasian aplikasi Nagari Cash Management kepada pihak Bank Nagari selalu terlambat dapat respon yang lambat. Upaya dalam mengatasi kendala yang muncul dalam pelaksanaan transaksi keuangan secara non-tunai di Sekretariat Derah Provinsi Sumatera Barat adalah salah upaya yang dilakukan oleh Badan Kuangan Daerah Provinsi Sumatera Barat adalah mengadakan kegiatan pelatihan atau pembinaan yang bernama 'Coaching Clinic' yang bertujuan untuk membina dan meningkatkan kemampuan pegawai dalam menggunakan aplikasi Nagari Cash Management sebagai instrumen pengelolaan keuangan daerah berbasis sistem online.

\section{DAFTAR PUSTAKA}




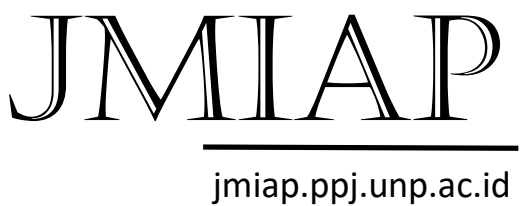

Instruksi Gubernur No. 3 Tahun 2017 tentang Pelaksanaan Transaksi Non-Tunai Jupri, Muhammad. (2014). Upaya Badan Kepegawaian Daerah dalam Proses Pengangkatan Tenaga Honorer Menjadi Pegawai Negeri Sipil Di Kabupaten Tanah Tidung.Jurnal Ilmu Pemerintahan Volume 2 Nomor 2

Mardiasmo.(2009). AkuntansiSektorPublik. Yogyakarta: ANDI

Muchlis, Hamdi. (2014). Kebijakan Publik. Bogor: Ghalia Indonesia

Mulyadi, Deddy. (2016). Studi Kebijakan Publik dan Kebijakan Publik. Bandung: Alfabeta

Nawawi, Zaidan. (2013). Manajemen Pemerintahan. Jakarta: Rajawali Press

Peraturan Pemerintah Nomor 58 Tahun 2005 Tentang Pengelolaan Keuangan Daerah

Pramono, Bambang, dkk. (2006). Dampak Pembayaran Non-Tunai Terhadap Perekonomian Dan Kebijakan Moneter. Bank Indonesia: working paper

Purwanto, Erwan Agus dan Dyah Sulistyastuti. (2012). Implementasi Kebijakan Publik: Konsep Dan Aplikasinya Di Indonesia. Yogyakarta: Gava Media

Siagian, Sondang P. (2008). Sistem Informasi Manajemen. Jakarta: Bumi Aksara

Sutabri, Tata. (2005). Sistem Informasi Manajemen. Yogyakarta: ANDI

Sholeh, Chabib\&HeruRochmansjah. (20100. Pengelolaan Keuangan Desa. Bandung: Fokus Media

Setyaningrum, Rina Moestika\&Fauzan Hamidy. (2008). Analisis Biaya
JURNAL ILMU ADMINISTRASI PUBLIK

Email : jianfis.unp@gmail.com Vol.1 No.1 Tahun 2018

Produksi Dengan Pendekatan Theory Of Constraint Untuk Meningkatkan Laba. Jurnal Riset Dan Ekonomi. Volume 8 Nomor 1 Surat Edaran Menteri Dalam Negeri Nomor 910/186/SJ tahun 2017

Widodo, Joko. (2001). Good Governance Telaah Dari Dimensi Akuntabilitas Dan Kontrol Birokrasi Pada Era Desentralisasi Dan Otonomi Daerah. Surabaya : Insan Cendekia 